\title{
Character Constitution in Heinrich von Kleist's Der Findling and Emily Brontë's Wuthering Heights
}

\begin{abstract}
The aim of this study is to examine the similarity of character constitution in Kleist's short story and Emily Brontë's novel, which seems to work in a diversity of identity creating attempts supplied by the characters themselves, the multiplicity of narrative voices as well as by the reader. The exploration of the identity quest is based on the analysis of the rhetorical ways of creating an origin for the foundlings by the use of nature analogies, through moral discourse and social positioning. The foundling figures in both narratives are closely connected with corresponding female characters and their identification process is interrelated. I will argue that in both texts, due to the complementary nature of individual figures and the complexity of the narrative design, identification attempts fail on all levels, thus character constitution itself is necessarily frustrated.
\end{abstract}

At first sight it might seem an absurd project to try to find any meaningful parallels in a comparative analysis of two texts, Der Findling and Wuthering Heights, that are not directly related to each other. They come from two distinctly different linguistic and cultural backgrounds; they are set widely apart in time, the dates of publication being 1811 and 1847 respectively; and they are the compositions of authors who differed in gender and most certainly never heard of each other. One more important factor that makes difference more obvious than similarity is the difference in narrative medium: Wuthering Heights is a novel whereas the Der Findling belongs to the genre of the short story. Their use of narrative techniques also differs. The novel applies a multilevel narration where the narrative of one character is embedded into that of the other, both narrative voices, though being conventional in different ways, are emphatically set against the destructive passion they are supposed to transmit. The short story is also built upon the contrast between the characters' intensity of moves and the mostly matter-of-fact style of narration. Still, in the novel the narrators get involved to a greater or lesser degree, in the short story an illusion is created

The AnaChronisT (2004) 31-45 ISSN 1219-2589 
by the author of the neutral attitude of an omniscient and trustworthy narrator, but, in fact, the narrative voice's reliability is limited to the particular scene it narrates, and shifts perspectives even there.

In spite of all these differences, there are a number of remarkable analogies that provide valid grounds for the comparative analysis of the two texts. Such are the foundling figures, the repeated substitution of family-members, instances of character naming and repetitive illnesses and deaths. A few attempts have been made so far to compare them, usually together with other Romantic texts: Cecil Davies sees them related in blurring genre boundaries and regards Wuthering Heights as a text written in the framework of the tradition of the 18th-century German short story as an example of which Der Findling is also categorised, ${ }^{1}$ and Carol Jacobs describes them as narratives that both exclude their readers from a teleological reading, i.e. from the possibility of interpretation. ${ }^{2}$

My comparison also aims to point out some ways in which these texts behave similarly. I will follow up the attempts at identification that apparently promise to give coherence to characters and show how they fail in the end. The status of the foundlings, their lack of origin, naturally raises the question of identity. The other characters, the narrators and the readers make repeated attempts to provide them with some kind of selfhood by associating them with physical objects, with natural phenomena as well as by defining them in a moral and social context. The narratives create a mirror effect by the continual presence of the two female characters, which supply "the other" in the identification process. Since, however, the female characters are also in search of identity, the foundlings and their counterparts assume the function of mutual sources of identification for each other. Whenever this contrastive process fails, selfexpression takes alternative routes such as psychosomatic reactions or illnesses. If the mistake is too great, the result is death. Looking into these analogies, both texts richly lend themselves to different methods of interpretation, each adding to a more comprehensive understanding. As opposed to naïve reading, J. Hillis Miller describes all critical approaches to literary texts as acts of demystification, the two main forms of which are rhetorical, i.e. attentive to linguistic devices, and ideological, i.e. looking for referential verities such as class, race or gender. 3

1. Cecil Davies, "Art within a Tradition: Wuthering Heights and the German Novelle," Brontë Society Transactions 17 (1978), pp. 202-203.

2. Carol Jacobs, Uncontainable Romanticism: Shelley, Brontë, Kleist (Baltimore, London: John Hopkins, 1989), p. ix.

3. J. Hillis Miller, On Literature (London: Routledge, 2002), pp. 122-123. 
In the following, these forms of reading will be mingled, thus the analysis enters deconstructive as well as comparative motif analysis oriented and gender sensitive discourses.

\section{The foundlings: natural and mythological analogies}

"But where did he come from, the little dark thing, harboured by a good man to his bane?" ... And I began, half dreaming, to weary myself with imaging some fit parentage for him, and repeating my waking meditations, I tracked his existence over again, with grim variations, at last, picturing his death and funeral ... and, as he had no surname, and I could not tell his age, we were obliged to content ourselves with the single word, "Heathcliff."4

This is how one of the narrators, Nelly Dean, ponders upon Heathcliff, trying to conjure up possibilities of an origin for him, but she does not succeed. The italicised words are a good example of what I am trying to prove, namely that there are repetitive attempts and accounts of character identification with endless variations. There is no similar textual reference as to the question of origin of Nicolo in Der Findling, the title, however, implies that this controversial problem remains unresolved per definition. 5 The origin, genetic and biographic, stays a riddle and provides no frame for constituting either foundling's identity.

In view of their absence of origin, the foundlings are read as if they belonged either to sub- or to superhuman realms. Heathcliff, for example, is abundantly associated with different animals. The most characteristic reference may be the metaphor of the cuckoo, which Nelly uses to describe his history to Lockwood: “It's a cuckoo's, sir - I know all about it, except where he was born, and who were his parents, and how he got his money, at first ..." (WH, 50.). Helena M. Ardholm, who conducts an

4. Linda H. Peterson, ed., Emily Brontë, Wuthering Heights: Case Studies in Contemporary Criticism (Boston: Bedford, 1992), p. 279 (my italics). All subsequent parenthesised references to the text of Wuthering Heights, marked as $W H$, will be to this edition.

5. Irmgard Wagner reports on the contemporary meaning of the word Findling, which describes a child abandoned by its parents, predominantly the mother. Irmgard Wagner, "Der Findling: Erratic Signifier in Kleist and Geology," The German Quarterly 64.3 (1991), p. 294. She also associates another meaning of the term describing Swiss and North German granite blocks with the story of the foundling on the basis of their inexplicable origin, p. 285 . 
emblematic research of the text, argues for the ungrateful nature of Heathcliff by analysing the emblem of the cuckoo and its subscriptions in emblem discourse. She underlines that the cuckoo is a bird that takes over alien nests, pushes out eggs or baby birds, lays its eggs but does not feed its offsprings, and uses one of the subscriptions to support her argument: "As soon as the changeling grows up, it steals the food from the rightful young and devours its benefactor with its jagged beak." Besides the description of the foundling's actions parallel to that of a cuckoo, it has also been pointed out that there is one more important trait the bird and Heathcliff have in common, namely their strong attachment to their chosen lifelong mate. 7 This is how one image can be used to underline different aspects of a character depending on the ideological background of the reading.

Both foundlings are ambiguously related to either god/heaven or evil/hell, depending on the actual narrative perspective they are seen from..$^{8}$ At the point he enters the family, Heathcliff is ambiguously evaluated by Mr. Earnshaw, his adoptive father: "you must e'en take him as a gift of God, though it's as dark almost as if it came from the devil" ( $W H, 51)$. Later, while he carries out his revenge plan, the dark side of his character is underlined and abundantly referred to by other figures: Hindley calls him the imp of Satan, Catherine a wolfish man, Isabella a lying fiend, a monster, not a human being, Nelly an evil beast and Joseph is convinced that th' divil's harried off his soul when he dies. This comprehensive picture might, of course, be misleading if the reader forgets that all these remarks are made through Nelly Dean's narrative voice mediated by Lockwood, ${ }^{9}$ consequently they cannot be taken for granted as judgements of Heathcliff's character but rather as signs of some beliefs and superstitions such as demonism, Satanism and lycanthropy common in

6. Helena M. Ardholm, The Emblem and the Emblematic Habit of Mind in "Jane Eyre" and "Wuthering Heights" (Göteborg: Acta Universitatis Bothoburgensis, 1999), p. 132. Interestingly, instead of giving a comprehensive emblematic analysis of the two novels, Ardholm ends up questioning the value-system emblem discourse represents.

7. Sheryl Craig, "Brontë's Wuthering Heights," The Explicator 52 (1994), pp. 157-159.

8. For a detailed analysis of the shifting meanings of moral terms cf. Marjorie Burns, " 'This Shattered Prison': Versions of Eden in Wuthering Heights," in Jeremy Hawthorn, ed., The Nineteenth-Century British Novel (London: Edward Arnold, 1986), 31-45.

9. For a deconstructive review of Lockwood's interpretative mistakes see: J. Hillis Miller, "Wuthering Heights: Repetition and the 'Uncanny,'” in: Peterson, Wuthering Heights, pp. $371-384$. 
Victorian literature. ${ }^{10}$ One example for this is the traditionally believed desire of the devil to imitate the father, which Heathcliff does by taking the position of all father figures. This is also reflected in the text when, in answer to Nelly's question who his master is, Hareton uses the term devil daddy. Though I describe them in different sections, note how the terms of nature analogy, moral discourse and social context mingle. The common sense mind would give Heathcliff's gestures an ethical relevance, still, the multiple perspective of interpretation creates a void where moral judgements are to be suspended, just as Dorothy Van Ghent remarks: "It is impossible to speak of him in terms of 'sin' and 'guilt' as it is to speak in this way of the natural elements or the creatures of the animal world." ${ }_{11}$

Similarly, all attempts at moral identification are frustrated in Der Findling: the narrative voice uses moral terminology, still, the framework of traditional Christian moral values is destroyed in the text, through the words' successively losing their meanings the moral discourse deconstructs itself. As László F. Földényi argues, the characters do not conform to traditional religious norms:

But there is no reliable God standing behind Kleist's heroes who could put an end to all earthly distrust. ... The missing divine, metaphysical guarantee from behind them comes alive within them. Chaos, hell and the grave threaten to devour Kleist's figures because they carry all of them within themselves. ${ }^{12}$

Just like Heathcliff, Nicolo is also ambiguously judged when he enters the tradesman's life: he is an orphan and described as the son of God: "the wardens of the hospital, upon the broker's asking whether the lad was free to get in, smiled

10. Marianne Thormählen interprets Heathcliff and his actions along the lines of a Faustian pact with the devil, cf. Thormählen, "The Lunatic and The Devil's Disciple: The ... Lovers' in Wuthering Heights," Review of English Studies 48 (1997), pp. 191-195, and Giles Mitchell investigates the connection between demonism, lycanthropy and Heathcliff's behaviour. Cf. Giles Mitchell, "Incest, Demonism and Death in Wuthering Heights," Literature and Psychology 23 (1973) 27-36.

11. Dorothy Van Ghent, The English Novel: Form and Function 1953 (New York: Harper and Row, 1961), p. 164.

12. László F. Földényi, Heinrich von Kleist: A szavak hálójában (Pécs: Jelenkor, 1999), pp. 177, 377 (my translation). 
and assured him that Nicolo was a son of God whom nobody would miss,"13 on the other hand, Piachi's son dies because of him. He even shows characteristics associated with the devil in folklore traditions of superstition, ${ }^{14}$ such as having black hair, cracking and eating nuts, let alone textual references like höllischer Bösewicht (devilish spirit) meaning his person or satanischer Plan (satanic plan) referring to his revenge plan. Just like in the case of the novel, here it is also important to note, that these remarks are made by the narrator whose reliability is questioned by the ever-shifting perspective.

\section{Social context}

The social identification of the foundlings happens through determining the everchanging roles they take up in the social unit of the family, which is accompanied by the continuous adjustment of their legal status as to proprietorship. Due to the repeated family reorganisations, the basic roles within the families are continuously reevaluated in relation to one another ${ }^{15}$ and the foundlings do not seem to fit any of these, they remain outsiders.

Heathcliff arrives at Wuthering Heights as a surrogate for the family's dead child, either as adopted or fathered out of wedlock by Mr. Earnshaw. ${ }^{16}$ This unclarified initial role of the son already shows that his function is void of meaning and challenges repeated interpretations. It is in the same manner Heathcliff acquires the role of brother to Catherine and Hindley, which, after Mr. Earnshaw's death, changes to that of a would-be lover and son/rival, respectively. His fatherhood to his own son is almost the opposite of Mr. Earnshaw's to him: he does not admit his own child

13. Heinrich von Kleist, The Marquise of $\mathrm{O}_{-}$, and other stories. Trans. Martin Greenberg. (New York: Ungar, 1973), p. 233. All subsequent parenthesised references to the text of Der Findling, marked as $D F$, will be of this edition.

14. Cf. Günter Oesterle, "Der Findling," in Walter Hinderer, ed., Kleists Erzählungen (Stuttgart: Reclam, 1998), p. 166.

15. Imre Kurdi describes Der Findling as a story in which the triangular family keeps multiplying itself. Cf. Imre Kurdi, "Liaisons dangereuses: Heinrich von Kleist, Der Findling, ein Kommentar," Jahrbuch der ungarischen Germanistik (1995), p. 48. Cf. also: “. . duplication of names, places, events, seems endlessly to re-enact itself, like some ritual that must be cyclically repeated..." (Sandra M. Gilbert \& Susan Gubar, The Madwoman in the Attic: The Woman Writer and the Nineteenth-Century Literary Imagination [New Haven: Yale UP, 1979], pp. 257).

16. Cf. Thormählen, p. 185 . 
into the family circle for too long. Thus, due to the undefinability of his function in the family, Heathcliff's social performance is a matter of perspective: he can be seen as anything from a strongly neglected illegitimate son and mistreated lover, acting rightfully by taking possession of the Earnshaw and Linton properties, to a monstrous intruder destroying families and usurping their wealth.

A parallel argument can be drawn in the case of Nicolo in Der Findling, who also enters the family with an unclarified status: he is an adopted surrogate for a dead child and at the same time also speculated on as Elvire's possible son. ${ }^{17}$ Later he assumes the position of a would-be lover to Elvire though he is married and competes with Piachi for the father role while he is father to his own child whom he neglects. So, Nicolo's assessment hovers between the same two extremes as Heathcliff's, that of the mistreated son and lover rightfully revenging himself and the satanic outsider destroying his benefactors.

It is tempting, in the case of both texts, to fall into the trap the denominations offer and interpret characters as combinations of different traits, such as Linton Heathcliff as a combination of the Lintons and Heathcliff, or the young Catherine as her mother, and Hareton as the second Heathcliff; still, it must not be forgotten that these characters only resemble but are not identical to one another. The same is to be kept in mind when examining the blurred identities of the characters of the Novelle: the names of Colino and Nicolo are made up of the same letters (also the name of Paolo ends similarly), together with the remarkable physiognomic similarity of the two, which give way to speculations like viewing them as doubles. I think that these possibilities show not only the variability of the characters' relationship to one another, and do not just break the boundaries of identity, but also deconstruct the possibility of any definition of relationships.

\section{The tool of identification: the whip}

It is not only in the context of the natural, the mythic and the social order that the foundlings frustrate identification; they also have a deep-seated connection with an object in the physical reality that defies definition. At the beginning of the novel Mr. Earnshaw asks his children what presents he should bring them from his journey, and while Hindley wishes for a fiddle, Catherine opts for a whip. Though broken to pieces, Hindley receives his present but Catherine's gets lost while Mr. Earnshaw

17. Cf. Andrew J. Webber, "Kleist's Doppelgänger: an Open and Shut Case?" English Goethe Society 63 (1992-93), p. 111. 
attends to the foundling, who is thus seen as a substitute present: Catherine's whip. Feminist critics regard the whip as a phallic symbol identical with Heathcliff, who symbolises male power. Catherine's choice of it is interpreted as an expression of the female wish for power in patriarchy, and after she receives it in the shape of Heathcliff, she is viewed as a perfect androgyne. This term is applied to underline that Catherine has the same amount of male and female characteristics, especially if Heathcliff is seen as her double. Later, as she has mental and physical problems, it is maintained that the whip is turning against her, and that she is figuratively whipping herself. 18

Self-inflicted pain and sexual pleasure are also mentioned by Kleist-critics examining the function of the whip in Elvire's life. Attention is called to the fact that Elvire has once already been whipped by the windstorm when she was saved by Colino, thus "[i]t is in the whip where resignation, death, danger, sexual delight, selfreproach, play and hatred are concentrated." 19 The whip is also regarded as a device serving as a substitute for verbal communication when Piachi takes it off the wall and shows Nicolo the way out with it. This is a stage of aggression, which is beyond communication. ${ }^{20}$ Thus, just like in the novel, the whip seemingly has to do with power and sexuality, still, besides this signalling gesture, it is never shown in use, therefore, its function can only be speculated on by strongly appealing to the readers' moral and ethical prejudices. ${ }^{21}$ It might represent masculinity in the case of the novel, a substitute for language in the Novelle or power in both, however, it would be opportunistic to reduce its meaning to any of these possibilities since it is a narrative gap. It is important, however, that the whip certainly functions as a strong connector between characters.

18. Gilbert \& Gubar, p. 264. Even Mr. Earnshaw's statement introducing Heathcliff can be read as an allusion to the whip or being whipped: "See here wife, I was never so beaten with anything in my life" ( $W H$, p. 51).

19. Földényi, p. 250 (my translation).

20. Gail M. Newman, "Family Violence in Heinrich von Kleist's Der Findling," Colloquia Germanica (1996), p. 289.

21. Cf. Dániel Lányi, "Was sucht die Peitsche an der Wand? Kleists Findling oder die Rolle des heuristischen Erkennens in der Interpretation," Jahrbuch der ungarischen Germanistik (1992), p. 366. 


\section{Self-identification through "the other"}

As it has already been suggested in the previous sections, there is a strong attachment to a connected female character in the case of both foundlings. The relationship between Catherine Earnshaw and Heathcliff and Elvire Parquet and Nicolo is so determining that it even serves as a means for self-identification for each of these characters. Looking at Heathcliff's revenge, for example, it is claimed, that it is not his actions which are important but the process he goes through, because that is the way he ensures his self a survival in isolation after Catherine's death. ${ }^{22}$ However, it is not to be neglected that Catherine and Heathcliff are not detachable from each other even after her death since they annihilate the life/death boundary when they define each other as their own selves:

"I shall not be at peace," moaned Catherine ... "I'm not wishing you greater torment than I have, Heathcliff. I only wish us never to be parted - and should a word of mine distress you hereafter, think I feel the same distress underground" (WH, 148).

Heathcliff's perspective is similar: "Catherine Earnshaw, may you not rest, as long as I am living! ... I cannot live without my life! I cannot live without my soul!” (WH, 154, my italics).

Thus, during the rest of his life, Heathcliff is in constant contact with Catherine through remembrances:

for what is not connected with her to me? and what does not recall her? I cannot look down to this floor, but her features are shaped on the flags! In every cloud, in every tree-filling the air at night, and caught by glimpses in every object by day, I am surrounded with her image! The most ordinary faces of men and women - my own features - mock me with a resemblance. The entire world is a dreadful collection of memoranda that she did exist, and that I have lost her! (WH, 274).

The question is how their relationship could be defined. Traditionally, they are regarded as star-crossed lovers finding no social acknowledgement for their passion and thus suffering a tragic end. However, I am more inclined to agree with the subtler point of view feminist criticism adopts, which distinguishes the unfulfilled

22. Thomas Vargish, "Revenge and Wuthering Heights," Studies in the Novel 3 (Spring, 1971), p. 14 . 
Romantic love, where sexuality is triumphed over by death, and the socially accepted romantic love, where sexuality wins over death and argues that Catherine wants both, but this option is refused by society. Patsy Stoneman also shows that because of her double choice, earlier criticism has judged Catherine negatively, for, it declined to accept her wanting to integrate both men in her life and rather saw this conflict as her inability to choose. ${ }^{23}$ Even her deterioration is interpreted in these terms, namely, that she develops different psycho-neurotic symptoms such as anorexia nervosa, fits and suicidal impulses eventually leading to her death, as an answer to the other characters' lack of understanding and empathy in the face of her passions which defy the prevalent rigid Victorian gender distinction. ${ }^{24} \mathrm{Op}-$ posing this view, some critics emphasise the perversion of emotions and regard the couple as an entity that does not know and fit into any concept of love: "Catherine and Heathcliff ... have no tenderness or compassion for anybody, not even for each other." ${ }^{25}$ In these texts the traditional concept of love does not seem to function, because the identification process of these figures seems to have priority over clear-cut emotions.

In the case of Der Findling, there is also a love-hate relationship depicted between Elvire and Nicolo, but just like in the novel, it is part of their attempt to find their identities and thus, subordinated to that process. Elvire hides her true self in her bedroom ${ }^{26}$ through an intensive relationship to a fetish, the picture of her dead beloved, Colino, but at the same time she also takes an intense interest in Nicolo's sexual life. However, when her secret is seriously threatened by the foundling, she fights to get rid of him:

And in fact Piachi, too, was inclined to end the whole thing as quietly as possible; struck speechless by a few words from Elvira, who cast a look of horror at the wretch when she recovered consciousness in the old man's arms, he merely took a whip down from the wall and, drawing shut the cur-

23. Patsy Stoneman, "Catherine Earnshaw's Journey to Her Home Among the Dead: Fresh Thoughts on Wuthering Heights and Epipsychidion," Review of English Studies 47 (1996), pp. 523-525.

24. Nóra Séllei, Lánnyá válik, s írni kezd: 19. századi angol írónők (Debrecen: Kossuth, 1999), p. 238.

25. Thormählen, p. 184.

26. Here the traditional key-symbolism is offered to the reader as a means to solving the riddle but, of course, "the truth" remains enigmatic. Cf. Jürgen Schröder, "Kleists Novelle Der Findling," Kleist-Jahrbuch (1985) 109-127. 
tains of the bed on which she lay, opened the door and gestured Nicolo to get out that instant $(D F, 245) .^{27}$

Similarly, Nicolo's emotions change when he thinks that Elvire wants to intrude upon his privacy: "This incident, which humiliated Nicolo deeply, awakened a burning hatred for Elvira in his heart, for he thought he had her to thank for the affront the old man had given him before all the world" $(D F, 238) .{ }^{28}$

It can also be seen how Nicolo's wish for an identity changes from wearing the mask of a Genevan knight unconsciously, to wanting to put it on for a second time with the purpose of identifying himself with the portrait in Elvire's room. Besides wearing the mask, that is, re-imag(in)ing himself, the foundling also rewrites his identity when he regroups the letters of his own name to that of Colino's, which has a strong effect on Elvire. As long as Colino functions as a/the channel of identification, it does not really matter if Nicolo is his double or not, as some critics claim.29 In this respect Colino is a neutral figure and his resemblance to or equation with Nicolo is a matter of perspective. $3^{\circ}$ As the story proceeds, Elvire and Nicolo's search is becoming increasingly interdependent: "Nicolo lets ... Colino come alive, to awake Elvire from her state of death-in-life ... and he wants to find himself leaving his non-existence behind the same way." ${ }_{1}$

Analysing the relationship of Catherine and Heathcliff, Dorothy Van Ghent points out that important boundaries are established between the conscious and the unconscious parts of the selves of these characters, which are symbolically represented throughout the novel..$^{2}$ However, I tend to agree with Elisabeth Napier, who claims that the importance of boundaries does not lie in their establishment but in the want of their dissolution: "the narrative is based on a scheme in which distinc-

27. The translation "he merely took a whip down from the wall" is a little misleading, since it might imply that there are more whips on the wall. The original text uses the definite article here: “. . . nahm er bloss ... die Peitsche von der Wand.” Cf. Helmut Sembdner, ed., Heinrich von Kleist: Sämtliche Werke und Briefe, Vol. 2 (München: dtv, 1984), p. 213.

28. The translation does not accurately follow the original text here either, since the word Unglücklicher, used to characterise the foundling, is an important instance demasking the make-belief of an impartial narrative voice the translator apparently falls victim to. Cf. Sembdner, p. 206.

29. Webber, pp. 107-111.

30. Marjorie Gelus, “Displacement of Meaning: Kleist's Der Findling,” German Quarterly 55 (1982), p. 545 .

31. Schröder, p. 119 (my translation).

32. Van Ghent, pp. 161-162. 
tions collapse and the limits between characters dissolve, categories are not bounded and discrete but undemarcated and fluid." 33 Carol Jacobs, in her comparative analysis of these two texts, focuses exactly on this problem of boundaries and comes to the same conclusion. 34

\section{Illness as a means for self-expression}

Illness is a recurring phenomenon in both writings. In effect, the actual telling of the stories is made possible by this notion, because the fates of the two families would never have been reported, if Lockwood did not become ill in the novel, and similarly, the events of the Novelle would not take place if there was not an epidemic, the Black Death with which Nicolo is infected. What I find particularly interesting is the parallel that can be drawn between Catherine and Elvire's nature and course of illness. Both develop nervous reactions to a possible trauma in their childhood. Elvire has to face the death of her rescuer whom she falls in love with and Catherine must put up with her separation from Heathcliff and his disappearance. The first time some symptoms of these reactions manifest themselves is when the trauma occurs: Elvire faces the loss of her hero again when she marries Piachi and Catherine has to come to terms with Heathcliff's disappearance which is connected to her marriage with Edgar. Besides the tears she cries for Colino, this time Elvire develops a very high temperature, and Catherine has a fit of crying which grows into a recurring feverish delirium: "People were accustomed to blame her fits of agitation on a strained nervous system, the result of a high fever into which she had fallen shortly after her marriage, and this put a stop to all inquiry into their cause" $(D F, 236)$; "It proved a commencement of delirium ... she had a fever. ... and serious threats of a fit that often attended her rages ... Edgar Linton ... believed himself the happiest man alive on the day he led her to Gimmerton Chapel" (WH, 92-93). The second time this happens is when the heroes, in full view of the female characters, return: Colino in the shape of Nicolo and Heathcliff as his old self after his long absence from the Grange: "Trembling in every limb, Elvira was put to bed, where she lay ill for several days with a raging fever" $(D F, 237)$; "I shall get wild. ... I'm in danger of being seriously ill - I wish it may prove true" $(W H, 114)$. These reactions are triggered for the third time in the most intense form by the female characters' last confrontation with

33. Elisabeth Napier, “The Problem of Boundaries in Wuthering Heights," Philological Quarterly 63 (1984), p. 95. Cf. also Mitchell, pp. 27-36, Stoneman, pp. 521-533.

34. Jacobs, pp. 61-81, 171-197. 
their male counterparts, which is in the case of both women fatal: "the unfortunate Elvira, who had died from the effects of a high fever brought on by the episode" ( $D F$, 246); "she was all bewildered, she sighed, and moaned, and knew nobody. ... that night, was born ... a puny, seven months' child, and two hours after the mother died, having never recovered sufficient consciousness" (WH, 151).

The reason for these illnesses may be the repression of sexual desire resulting in aggressive outbreaks leading to longer illnesses and deaths. Nóra Séllei treats illness in Wuthering Heights as a central motif that can closely be related to the characters' relationship to their bodies, sexuality and identity often resulting in the loss of these. 35 Kleist seems to use the motif in a similar way in Der Findling. According to Dirk Oschmann, through the extensive use of body language terms, Kleist's texts reflect the breaches of the body, identity or actions in breaches of expression, thus language is sensualised. ${ }^{36}$ Attention has also been called to the possible meanings of the mental imbalance to be depicted in both cases: Elvire's hysterical reaction is judged as a tool for avoiding reality, that is, it functions as a substitute for the belief in facts. 37 I do not think that it is made so clear by Kleist that these faints or fits are performed on purpose, whereas in the novel it is made obvious that Catherine chooses illness as a means of communication: "I am in danger of being seriously ill I wish it may prove true. He has startled and distressed me shockingly! I want to frighten him" $(W H, 114)$. This is also how Susan Sontag comments on sickness in her book Illness as Metaphor and AIDS and its metaphors, as a language that expresses the dramatisation of consciousness. 38

Not only Catherine and Elvire's psycho-neurotic tendencies are noteworthy in this respect, but also the psychosomatic reactions of Nicolo and Heathcliff: just like Elvire, Nicolo in many cases behaves like a shy schoolboy and develops physical signs of his psychological trembles: "Nicolo, turning red and white by turns ... and, quite unable to hide from Xaviera's teasing looks the embarrassment into which this

35. Séllei, pp. 205-210.

36. Dirk Oschmann, "How to Do Words with Things: Heinrich von Kleist's Sprachkonzept," Colloquia Germanica (2003) 3-26.

37. Erna Moore claims that this is exactly what makes Elvire similar to Piachi and both different from Nicolo, namely their substitution of reality for fiction. Erna Moore, "Heinrich von Kleists Findling: Psychologie des Verhängnisses,” Colloquia Germanica (1974), p. 282.

38. Susan Sontag, Illness as Metaphor and AIDS and Its Metaphors (New York: Doubleday, 1989), pp. 38-49. In this book Sontag analyses cancer and consumption, the latter being a typical illness of the 19th century, which was feared as being inherited from one generation to the next, especially by the Keats and Brontë families. 
disclosure had thrown him ... picked up his hat with an ugly twitch of his upper lip, said goodbye, and left" $(D F, 244)$. Heathcliff, on the other hand, shows strong masochistic and sadistic tendencies. Probably he dies of starving himself to death in the same way Catherine threatened to die earlier: "He took his knife and fork, and was going to commence eating, when the inclination appeared to become suddenly extinct. .. 'I am animated with hunger, and, seemingly, I must not eat' " $(W H, 277)$.

To sum up, I think that it can be established that both of these relationships are strongly interdependent, so much so that separation, probably metaphoric for the repression of the powerful erotic desire, leads to illness, psychic disturbances and the surfacing of the wish to die: Eros is replaced by Thanatos. This means that Catherine and Heathcliff as well as Elvire and Nicolo constitute an androgynous entity which cannot be seen as simply the interaction of the traditional male and female protagonists but rather as a unified identity defined by the organic nature of the bonds holding them together: as soon as the sexual drive making them into one is repressed, their body fails them as well: they become disturbed or get ill and die.

\section{Prosopopoeia and death - repeated}

As a further argument for the intractability of characters, I will use J. Hillis Miller's reading of Der Findling as a version of the Pygmalion story of Ovid's Metamorphoses, and also extend it to Wuthering Heights. 39 In his analysis there are a few short remarks referring to the novel, one of which underlines the foundlings' "Christlike" entering their new families, which, if of any importance at all, may strengthen their position as god-related and, at the same time, also give ground to speculation or disbelief. Miller argues that characters, narrators and readers are all unavoidably inclined to make mistakes while interpreting textual events. Interpretation is necessary for understanding, but understanding is governed by reason and reason binds events into causal chains to make them comprehensible. For example, Pygmalion identifies Galatea with the idealised image of a woman in his mind and acts accordingly, although her statue, which can only be brought to life through divine intervention, only resembles this idol but is not identical with it. The same types of mistakes are made in Der Findling, where characters also identify inanimate figures with animate ones: Piachi, the father adopts Nicolo, the foundling as a substitute for his dead son, Paolo. Elvire, Piachi's young wife and Nicolo's step-mother repeatedly falls into the trap of taking Nicolo for the dead Colino, the Genevan knight

39. J. Hillis Miller, Versions of Pygmalion (Cambridge, Massachusetts: Harvard UP, 1990). 
who saved her life. Nicolo makes the mistake of identifying himself with Colino based on his similarity with the dead knight. Heathcliff is also viewed as a substitute for the family's dead son and is even given his name by the Earnshaw-parents. The daughter of Catherine gets her mother's name, who dies in childbed, and all figures with combined names are implied to expect similar destinies to their predecessors whose names they bear and whose identities they inescapably assume. Mentioning the novel shortly, Bettine Menke calls the attention to the dangers of the figure of prosopopoeia as one that increases the uncertainty of interpretation by its nature, figuration and defiguration happening at the same time..$^{\circ}$ So the identification of individual figures is questioned and the focus is rather on their interactive modification. 41

Thus, it can be concluded, there are similar linguistic and narrative tools used by Kleist and Brontë which subvert the ideological reading of the texts. The most obvious of these are the attempts to validate the reading of the characters of unknown origin and their actions both as god-given, thus benevolent, and as stemming from the devil; to attribute to these fluid figures widely differing social roles such as that of a member of a nuclear family from prodigal son to revenging father or the participant of a love relationship as ever-loving or unfaithful. The deaths of certain figures easily seem to lend themselves to ideological interpretation, which, however, becomes nullified by the repetitiveness of the motif as a reinforcement of interpretative mistakes, thus this event also remains pure functionality. Thus readers must be content with the conclusion that in both texts obtaining a comprehensive picture of individual characters and their actions, even if there were such, is made impossible.

40. Bettine Menke, Prosopopoiia: Stimme und Text bei Brentano, Hoffmann, Kleist und Kafka (München: Fink, 2000), p. 163.

41. Cf. Séllei, pp. 241-253; Gilbert \& Gubar, p. 255 for the Brontë text and Schröder, p. 113; Anthony Stephens \& Yixu Lü, "Die Ersetzbarkeit des Menschen: Alter Ego und Stellvertreter im Werk Heinrich von Kleists," Jahrbuch der Deutschen Schillergesellschaft (1994), p. 127; Wagner, p. 295 for the Kleist text. 